1975

\title{
Service Intellectuals and the Politics of 'Science'
}

Edward A. Purcell Jr.

New YorkLaw School, edward.purcell@nyls.edu

Follow this and additional works at: https://digitalcommons.nyls.edu/fac_other_pubs

\section{Recommended Citation}

Purcell, Edward A. Jr., "Service Intellectuals and the Politics of 'Science'" (1975). Other Publications. 400.

https://digitalcommons.nyls.edu/fac_other_pubs/400

This Article is brought to you for free and open access by the Faculty Scholarship at DigitalCommons@NYLS. It has been accepted for inclusion in Other Publications by an authorized administrator of DigitalCommons@NYLS. 


\section{Service Intellectuals and the Politics of "Science"}

Charles Sumner Slichter: The Golden Vector, by Mark H. Ingraham. Madison, Wisconsin: The University of Wisconsin Press, 1972. $316+$ xiii pp. (cloth)

Charles Kenneth Leith: Scientific Advisor, by Sylvia Wallace McGrath. Madison, Wisconsin: The University of Wisconsin Press, 1971. 255 + xii pp. (cloth)

Harry L. Russell and Agricultural Science in Wisconsin, by Edward H. Beardsley. Madison, Wisconsin: The University of Wisconsin Press, 1969. $237+$ x pp. (cloth)

The Intellectuals and the Powers and Other Essays, by Edward Shils. Chicago: The University of Chicago Press, 1972. $481+$ xiii pp. (cloth)

The term "intellectual" - denoting a specific type of person-is distinctively modern. It developed in Europe during the middle nineteenth century, and arrived in the United States at the beginning of the twentieth. The term represented one of the linguistic and conceptual responses that individuals made to the changing social conditions of modern society. Unlike such related terms as "academic," "scientist," "technician," "scholar," however, the concept of the "intellectual" became the subject of debate and controversy. It did so, not only because the term served a variety of purposes, but more importantly because it was essentially a moral concept. An "intellectual" was one who was supposed to both discern the truth personnally and uphold it publicly. An "intellectual," therefore, was an individual who acted under a special obligation and responsibility. The question of the "proper" role of the intellectual became a characteristically twentieth century concern. (1)

While writers have offered various prescriptions for that role, perhaps the most common view in America has been that the intellectual should combine the best of two worlds. He should be critically objective yet socially involved, detached but practical, speculative but useful, moral but cooperative. To many the ideal intellectual became the "service intellectual." The attractiveness of such an image, or self-image, is obvious. Its potentially self-contradictory nature is equally obvious.

The University of Wisconsin Press has recently published biographies of three scientists whose careers unfolded on the Madison campus. Together they help illuminate the history of American higher education, the history of 
applied science, and the history of the "service intellectual." In spite of differences the three volumes point to some similar conclusions. All three of the scientists, for example, enjoyed a high degree of upward social mobility, yet their origins were in a relatively educated and economically stable middle class. Hence they reinforce the contention that the upward mobility that the universities fostered at the end of the nineteenth century was a mobility that extended only occasionally below the middle class. The books illustrate, too, the extent to which the academics shared the economic values of the rest of their society. All three men earnestly sought financial success, employed their science for profitable ends, and ended their careers as rather wealthy individuals. (2) They believed that science should be "applied" and that its results would be benevolent. Their lives justified both beliefs. All three were socially conservative, institutionally adaptive, and technically oriented. Though their professional careers were more successful than most, they probably represented the social attitudes of many American academics. They reveal the diversity to be found among "intellectuals" and serve to remind us that the "liberal reformer" was only one type among many.

Mark Ingraham's biography of Charles Sumner Slichter is the least valuable of the three. The author, a mathematician and younger colleague of Slichter's for over twenty-five years, accepted the biographer's burden as a labor of affection for his friend. He rejects the historian's "paraphernalia of producing footnotes," and tries instead to merely record the life of a "colorful personality." (3) Unfortunately, he also rejects such things as research and analysis. "I have made no attempt to marshall all the evidence, some of it hearsay, for or against these conclusions," he explains at one point, "but have used some to tell the story of what happened." (4) While the reader can sympathize with both Professor Ingraham's attitude and his plight, the result must be disappointing to all but older and nostalgic Wisconsin alumni. The book, which relies on extensive and often undigested excerpts from Slichter's writings, is a kind of genial and reminescent thirdperson autobiography.

Slichter was born in Minnesota in 1864, the descendant of Swiss Mennonites who had immigrated to the United States in the late eighteenth century. Graduating from Northwestern University with a Bachelor's degree in 1885, he received an appointment in mathematics at Wisconsin the following year. Slichter worked in engineering and applied mathematics, enjoying the challenge of applying abstract formulae to the solution of practical difficulties. As a member of the United States Geological Survey, he began to specialize in problems of underground water flow, gradually developing an extensive consulting career dealing with irrigation and urban water supplies. Apparently a popular and slightly unorthodox teacher, he became a well known and influential campus figure. As Chairman from 1906 to 1920 he cooperated with Edward Van Vleck in building the department into a major center of American mathematics. From 1920 until his retirement in 1934 he served as Dean of the Graduate School. Slichter focused much of his effort on enlarging the University's support for scholarly research of all types, and he wạs a major figure in establishing the justly famed Wisconsin Alumni Research Fund. 
Given the nature of the book, it is difficult to evaluate Slichter's career. One assumes that all of those people, including the central figure, were not always that nice and that jovial. Still, Slichter does come alive in places as a likeable individual who was an effective administrator. His success was undoubtedly based more on his personal character than on his intellectual achievements. The book catches a bit of the flavor of the late nineteenth century classroom, and it touches on such things as the growth of academic consulting and of administrative bureaucracy. What scholarly value it possesses, however, lies only in the increment of raw materials it provides for the historian of the American university.

Sylvia Wallace McGrath's biography of Charles Kenneth Leith is fortunately more reliable and more revealing. The author is careful and thorough; the book is well researched. Its most significant parts deal with those crucial areas where academic science overlaps with problems of government policy and economic development. It tends to become rather vague when treating Leith's early years and his personal life, but that may well be due to a scarcity of source materials. Discussions of his technical achievements are also rather vague, and it is occasionally not clear what their precise significance was. On the whole, however, the book is both useful and informative.

Born in a small Wisconsin town in 1875, Leith entered the state university in 1892 and soon found himself fascinated with the geological researches of Charles R. Van Hise. Quickly becoming Van Hise's protege, Leith finished the Ph.D. under his direction and then joined the department. As Slichter had done, Leith began working with the U. S. Geological Survey, and he soon established himself as an expert on the Lake Superior mining regions, specializing in problems of rock cleavage and pre-Cambrian geology. He also developed, with Van Hise, an extensive and lucrative consulting practice, at one point touring the Lake Superior regions in the private railroad cars of United States Steel. During the First World War Leith served as a special consultant to the United States government on wartime mineral supplies. From that experience he developed an interest in national mineral policy and the economic and political problems that affected world trade. He advocated a unified national policy that would provide a rational basis for American mineral usage, exploiting only the internal supplies that were plentiful and opening up world resources-especially in domestically scarce commodities-for American development. Enjoying little success in the twenties, Leith fared somewhat better under the New Deal. Still it was not until the Second World War that the need for a national mineral policy seemed compelling. Once again, in time of war, his efforts were important in helping to secure and allocate the vital raw materials necessary for American industry. After the war Leith turned his attention to the mineral problems related to atomic energy. In 1956, shortly before his death, the Atomic Energy Commission presented him with a special citation for his "significant contribution to his country's security and welfare." (5)

Charles Kenneth Leith: Scientific Advisor provides a useful account of a significant career. Its major weakness lies in its failure to use materials to help illuminate broader themes. Leith was, for example, closely associated with the business community. He invested heavily in a number of ventures 
and was often involved with Van Hise in land speculations arising out of his geological explorations. For many years Andrew Carnegie financed their enterprises. Van Hise keeping the partnership a secret since he "feared that his connection with Carnegie would be misinterpreted." (6) Leith consulted for a number of mining and industrial firms, and on many occasions he represented their interests before state and federal officials. He was convinced, too, that the scientific strength of the Wisconsin department depended in large part on close connections with the corporations that could fi. nance geological explorations and provide positions for the department's graduates.

Beyond the many potential conflicts-of-interest in which Leith was inevitably involved lay the broader questions of the extent and nature of the influence that business corporations and the quest for personal wealth have exerted on the course of American science and education. In specific ways business demands have helped determine the development of both; in a more general way business values have helped create the very cultural basis out of which both have grown. While there may be aspects of "science" that are truly "objective," there are others that are determined by the cultural and social institutions within which "science" functions. Leith's career could have served as an enlightening case study of those interrelationships.

Unfortunately Professor McGrath devotes relatively little attention to Leith's political and social ideas, emphasizing instead his general belief that "the scientist had an obligation to use his science in the practical conduct of human affairs." (7) The implicit assumption seems to be that the practical use of science was essentially an obvious and non-partisan process-the application of "objective" methods to merely "technical" problems. Yet is is clear, especially in his role as a planner, that the policies Leith suggested were themselves determined as much by his political and cultural orientation as by "science." The author notes that one of Leith's reports "looked at mineral problems from the broad self-interest of the United States," (8) but she ignores the fact that his proposals were much more political and partisan than that. Leith stood for an "open door" policy in relation to world mineral development, a policy that would allow American industry to exploit the resources of other nations. Most revealingly, he conceived of the central conflict as one between "the world demand for minerals, which tended toward international unification, and the 'nationalistic forces directed toward partitioning resources for national gain and security'." (9) The first attitude, he assumed, was based on scientific study and rational planning; the second was based on willful ignorance and narrow selfishness. While the latter represented the demands of partisanship, the former represented the demands of "the world." That America and her corporations might themselves be partisan, narrow, or selfish apparently did not deter him. Through a rhetorically objective but functionally partisan rationale of market demand and efficiency he in practice largely equated "the world demand" with the actual needs of American business. Here indeed was "objectivity" serving the demands of a specific ideological and economic viewpoint. While Leith's attempt to extend American power and influence was certainly unexceptional for one serving as a representative of the government, conceiv- 
ing of that attempt as scientifically "objective", and therefore non-partisan, is both distorting and misleading. Leith evidently accepted it as such, and so, apparently, does Professor McGrath.

Leith, of course, was not merely an apologist for American business. While he continually defended the interests of the mineral industries, he viewed himself as bringing a rational, scientific approach to national planning. After World War I he suggested that the accumulated data on mineral supplies could provide a "sound basis for planning a proper distribution and use of raw materials of the earth." (10) In such a context "proper" was hardly a scientific word. It was, in fact, precisely because Leith could conceive of himself as a scientist, and therefore as "objective," that the implicit cultural and economic biases in his plans could go unnoticed and unanalyzed.

Leith's career thus raises not just the issue of science as a guide for policy but more importantly the problem of how cultural values and individual preconceptions inform the very concept and meaning of science that individuals hold. Leith was fairly and honestly a man of science and reason, yet those terms stand, not for neutral objectivity, but for varying types of evaluative intellectual frameworks. In order to understand Leith's function as a scientific advisor, then, it is first necessary to understand the set of perceptual and evaluative assumptions that informed his view of what exactly "science" was and how it operated. Those preconceptions were intimately related to the values of American business, and hence those policies that served the needs of business appeared to him as objectively rational and scientifically efficient.

The book's conceptual framework, captured in the subtitle "scientific advisor," proves too cumbersome to adequately evaluate Leith's role. "His career," Professor McGrath declares, "heralded the rise of such advisors to positions of power and influence in American society." (11) As an indication of a general change in American life, of the employment of experts in government positions, it is surely a fair statement. Beyond chronicling that development, however, the more important question would seem to be the nature of their employment and the extent of their "power and influence." Professor McGrath's biography adds to our knowledge of the "scientific advisor" and suggests the varied experience that such individuals have undergone. Historians in the future, however, need to examine that variety more closely: to question the assumptions and purposes of such advisors, to analyze the meaning and function of "science" in their careers, and to weigh the exact nature of their activities and influence.

Many of the broader educational and intellectual problems that Leith's career raises also reverberate through the life of Harry L. Russell, a contemporary of both Slichter's and Leith's and for many years the Dean of the University of Wisconsin College of Agriculture. Growing up in the small Wisconsin town where he had been born in 1866, Russell was early introduced to the biological sciences by his father, a physician, and by his mother who had a well developed knowledge of botany. He pursued his scientific interests as both an undergraduate and a graduate at Madison, and then spent the year 1890-91 studying in Berlin, Naples, and Paris. Returning 
to the United States he took a Ph.D. in biology from Johns Hopkins, specializing in the embryonic field of plant bacteriology. After a year teaching at the University of Chicago, Russell returned to Wisconsin in 1893 as an assistant professor in the College of Agriculture. Focusing his attention on problems relating to the dairy industry, he used scientific research to improve the quality of agricultural products and to protect the health of the consuming public. His stature within and without the university grew, and in 1907 he was appointed Dean of the College. Gradually his interests shifted from research itself to the institutional problems of the College and to broader issues of state and national agricultural policy. Russell continually stressed the need to expand agricultural production, often ignoring the economic and social plight of the farmer; by 1912 he was becoming a favorite target of Wisconsin Progressives. Educationally Russell was an empire builder, constantly pushing to expand the College through growth, diversification, and exclusive control over state agricultural extension programs. He turned the College into a major research institute, arguing for more and more basic research, and in the twenties joined with Slichter and a few others in founding the Wisconsin Alumni Research Fund. Resigning his deanship in 1931, he served until his retirement in 1937 as WARF's director.

Edward H. Beardsley's biography of Russell is enjoyable, well written, and thoughtful. It charts the rise of a sophisticated agricultural science during the first decades of the twentieth century, pointing out its achievements as well as its limitations. Beardsley delineates the social and political context which surrounded and influenced Russell's efforts, and he emphasizes the scientist's shrewd ability to work within those given confines. Russell's determined campaign to combat bovine tuberculosis, for example, included public debate, open demonstrations, and legislative lobbying in addition to scientific research. Beardsley's study has the additional advantage of providing a kind of middle level view of the transformation of the American university. While much of the historical literature provides either an overview through the lives of the great presidents or a disciplinary view through the work of major researchers, Beardsley offers the perspective of an administrator, powerful but not dominant, who was faced with the day to day problems of institutional change, who was both scientist and bureaucrat. It is an admirable work of historical scholarship.

While the author, like so many biographers, shows a certain fondness for his subject, he nevertheless retains a critical perspective. Though he exonerates Russell of many of the charges that progressives such as Charles McCarthy levelled at him, Beardsley nevertheless traces Russell's growing aloofness from the state's farmers and his steady commitment to farm productivity instead of farm income. Russell was both an economic and social conservative, and after 1917 the Wisconsin progressives in his mind easily became "Bolsheviki." (12) During the war he served under Herbert Hoover in the Food Administration, and his conservatism together with his "lack of emotional identification with farmers" easily translated into a manipulative, bureaucratic approach to problems of wartime production. (13) He responded to the protests of his former constituents with organized and stern appeals to patriotism. 
Throughout much of his deanship critics accused Russell of fitting the policies of the College of Agriculture to the demands of bankers, real estate speculators, and other non-farm groups. Beardsley generally defends Russell, acknowledging only one clear and specific case where a major policy innovation significantly and favorably affected his personal real estate investments. In looking for such obvious conflicts-of-interest, however, the author sometimes downplays the more general conflict-of-interest engendered by Russell's basic social attitudes. To the extent, at least, that the dean of a College of Agriculture is supposed to heed the interests of the state's farmers, Russell frequently failed in his duties. He was inattentive and even callous. Agricultural problems for him were to be solved within a framework congenial to the bankers and land developers with whom he was so closely associated.

Russell's scientific outlook, together with his social assumptions, led him to conceive of the problems of American agriculture as "technical" problems. He focused, therefore, on such manageable and restricted areas as increasing productivity and improving quality. He ignored difficulties that could not be so readily resolved or so easily defined in strictly physical terms. Russell's concept of agricultural science, therefore, stemmed in part from implicit social assumptions, and its practice had, in turn, indirect but significant political implications. "Science" indicated to him that certain problems were soluble and that others were not.

Russell's career suggests the same problem that Leith's raised: the extent to which "science" in fact grows from and serves partisan and ideological purposes. Beardsley's study delineates one of the ways that the process can work, and it suggests the ideological bias of Russell's professional work. Still, however, it shares, though to a lesser extent, the same interpretative assumption that marks the books of Ingraham and McGrath. That assumption is that the history of the modern university and of the "service intellectual"-and to some extent the history of twentieth century America-is the history of the rise of scientific progress, rationality, objectivity, and benevolence. The problem is not that such an interpretative theme is wrong, but rather that it is biased and partial. It can lead historians to overlook the problems that science creates or the ones it cannot solve. It often ignores the extent to which science serves some social groups at the expense of others; the extent to which science is channelled by the demands of social institutions; the extent to which science is itself only a partial way of looking at the world; the extent to which science itself is based on cultural preconceptions. (14) In short, such an interpretative framework leads one to believe that "science" is a clear, unified, and objective phenomenon, obscuring the variety of "non-objective" personal, class, religious, or cultural evaluations which in fact help determine the specific meaning and utility that "science" has for different individuals. The twentieth century surely represents the rise of science in the sense that scientific activities have proliferated and had a great impact on societies. But no longer can we accept the eighteenth century assumption that the rise of "science" is equally the rise of a humanitarian progress and an objective truth. We must begin to look more penetratingly at what its actual consequences have been in a variety 
of situations and for a variety of groups. We must also begin to inquire more deeply what "science" itself really is.

Perhaps more than any contemporary American scholar Edward Shils has studied the significance and role of such institutionalized, scientific intellectuals as Slichter, Leith, and Russell. He has asked pertinent questions about the social implications of science and about the social assumptions of a wide range of intellectual types, from radical ideologues to bureaucratic functionaries. He has also reached some forceful conclusions. The Intellectuals and the Powers and Other Essays brings together many of his previously published papers on the functions, attitudes, and responsibilities of the educated classes. The volume contains a series of stimulating theoretical outlines and often perceptive case studies. The title essay itself, though over fifteen years old, still remains one of the most useful summaries of the subject available.

Shils stands forth proudly as a spokesman for that generation of American social scientists which grew to intellectual maturity in the late thirties and rose to prominence during the forties and fifties. "In the 1930s," he writes in his introduction, "I witnessed with revulsion the rush of the Gadarene intellectuals in the United States and Europe into the arms and snares of their respective communist parties." That experience revealed "the capacity of intellectuals in politics for folly and malevolence." (15) The post-war prosperity that the United States enjoyed, coinciding with personal success, taught most of the members of that generation the basic goodness of America's institutions and the fundamental necessity for their preservation. McCarthyism further taught them that danger lay with uneducated and disaffected masses, and with intellectuals and politicians who might support their "populistic" attempts to subvert stable social institutions. The major political question, then, became whether members of the scientific and scholarly communities would "have sufficient strength of character and devotion to their intellectual traditions to withstand an uncritical populism on the one side and the winds of frivolous doctrine which blow up from time to time among intellectuals on the other." (16) "Populism" and "ideology" thus evoked the image of two acient myths, Scylla and Charybdis.

Shils' essays mount a concerted attack on those two shibboleths. They argue that intellectuals should be scientifically objective and appreciative of the status quo, two attitudes which become synonymous. "The stability of the larger society," he declares, "depends, therefore, on the maintenance, within the culture and the institutional system of the intellectuals, of the predominance of that element which accepts an objective discipline and the integration of academic institutions into the central institutional system of American society." One of his avowed aims is to "reveal the fact that by no means all intellectuals have been in opposition to their societies." (17) The careers of Slichter, Leith, and Russell surely support such a contention.

At a time when many thoughtful Americans are growing more deeply concerned with what they see as the danger of the institutional incorporation of intellectuals, the business oriented and bureaucratic domination of social values, and institutional stability that borders on fatal rigidity, Shils sees the same phenomena but insists on their desirability. The problem with his book 
does not lie in the fact that it is a dissent from the latest intellectual fad. The difficulty is that it represents a partisan political ethic masquerading as "objective" science.

Shils' conceptual framework rests ultimately on a series of moral judgments and definitions, some explicit, some implicit. First, he judges the existing institutions of American society to be good. "The more valid aspirations of the older humanitarian elements which were absorbed into Marxism," he maintains, "have been more or less fulfilled in capitalist countries." Though presented in the form of a statement of historical fact, that sentence functions, in actuality, as a fundamental moral axiom. It is unproven and largely unanalyzed. In spite of the scientific rhetoric it is essentially an $a$ priori definition of an ethical standard. Those aspirations and ideals are largely "valid," Shils postulates, which have already been "more or less fulfilled." Those which have not been "more or less fulfilled" are, it logically follows, basically invalid. Thus Shils creates a moral system in which the status quo functions normatively to define which social ideals are morally acceptable and which are impractical, dangerous or evil. "It seems almost as if what was sound in the older ideologies has been realized," Shils argues, "and what was unsound has demonstrated its unsoundness so obviously that enthusiasm sustained by reason can no longer be summoned." (18) The status quo thus serves not only as a moral criterion, but it equally establishes the bounds for determining what is even "rational."

Viewing the capitalist countries as manifestations of the good society, Shils replaces the idea of social "conflict" with that of "tensions," which are consistently described in terms of "center" and "periphery." Through such a metaphor, Shils conceives of the society as a smoothly functioning unity characterized by the ready flow of individuals and programs toward a "center" which regulates the political concensus. There is no place for irreconcilable social divisions and no suggestion of organized oppression. The metaphor suggests, of course, the opposite: society is tranquil and there is a ready opportunity for "the narrowing of the distance between center and periphery." (19)

Second, Shils conceives of the "intellectual" in vague and diffuse terms. The word takes on different meanings in different contexts, and on occasion it seems that anyone who does anything that requires some kind of special training is an "intellectual." Essentially he assumes a contentless, functional definition: "Those who perform intellectual roles constitute the intellectual classes." (20) The term "intellectual" has, of course, always been imprecise, and Shils is privileged to define it any way he chooses. It is fair, however, to consider the implications of his usage.

The broad and contentless definition enables him to include innumerable social groups in the "intellectual class" (bureaucrats, civil servants, technicians, planners, etc.) and thereby to prove easily that "intellectuals" are varied, practical, important, and crucial to the operations of modern society. Of course, he has "proven" very little; rather he has merely elaborated his initial definition. His conclusions are essentially tautologies. It is all based on a circular argument. His assumption of the goodness and rationality of the status quo leads him to believe that large numbers who serve it are truly 
"intellectuals," while the fact that so many "intellectuals" serve established institutions in turn confirms that the status quo is good and rational.

By defining "intellectuals" as largely "at the center" of American society, Shils is able to deduce the logical corollary: there is little or no reason for a sense of alienation, helplessness, or disaffection on the part of intellectuals. Occasional sharp criticism, therefore, must arise not from a perception of substantive weaknesses in the society, but from a self-imposed existence at the periphery that a minority of "intellectuals" accept. "The most alienated are primarily concentrated in the functionally most marginal roles." (21) Thus Shils' definition allows him to prove that intellectuals are honored and influential within the status quo, and that peripheral disaffection is just that - a function of sociological marginality. The conclusion easily follows: intellectuals who reject the status quo are driven by social frustration not by critical judgment. Society can, therefore, safely dismiss the objections they raise.

Shils' amorphous, functional definition further allows him to drain the term "intellectual" of its traditional connotations and moral significance: problems of quality and substance disappear. The definition quietly shifts the basis of judging intellectual work from an evaluation of quality and substance to the function of institutional support. Such a functional definition is not "objective," it is merely misleading. It abandons explicit criteria of intellectual excellence for implicit ones. And the implicit ones are not in fact intellectual at all, but social. An "intellectual" is good, or as Shils would more "objectively" say, "responsible," when his "products" serve the cause of stability and the status quo. Ironically, Shils seems to share one of the basic assumptions of the Communist Party which he attacks. The proper role of the intellectual, both believe, is to serve a specific and established political structure. Indeed, Shils' definition seems almost identical with the official Soviet position which defines intellectuals as "a social stratum consisting of people who are occupied professionally with mental labor." The Soviet definition has abandoned any connotations of "critical" thought, Martin Malia has written, and instead it refers descriptively to "the technological, liberal-professional, managerial, administrative, or merely whitecollar personnel of the state." (22)

Finally, and most centrally, is Shils' concept of "ideology," the Satanic term of his moral universe. Ideologies, he explains, are "comprehensive patterns of belief" that are rigid, closed, authoritative, intensely compelling, theoretically explicit, and morally absolutistic. "Ideology seeks to sacralize existence by bringing every part of it under the dominion of the ultimately right principles." (23) Hence, ideologies lead to irreconcilable strife, turmoil, fanaticism, dogmatism, and all sorts of other social evils. They inevitably endanger stability and the status quo. "In reality, of course," Shils acknowledges, "the ideological quality never completely supplants all other qualities." (24) Though he recognizes that he is creating an abstract social typology, he justifies it on the basis of its analytical usefulness and empirical importance. Its real function, however, like that of his other concepts, is to create a moral discourse which defines the status quo as good but which sounds scientific. 
Empirically, Shils' concept of "ideology" distorts both the past and the present. Not only is the "ideological quality" not found in pure form in the real world, but such a focus serves to artificially constrain the understanding of social processes. To the extent that certain attitudes are "ideological" in the sense of his definition, they tend to be either politically peripheral or significant because they are intimately related to a variety of conflicts arising from the structure of society. In the former case they are unimportant; in the latter they comprise only one element of a complex situation. To the extent that other attitudes are not "ideological" according to his definition, they tend to take on a quality of rationality and objectivity which is misleading and often dangerously self-serving. The major distortion arising from his definition, then, is not that "ideologies" neither exist nor are important; it is, rather, that it narrows the word's meaning in such a way that many profoundly political orientations, such as Shils' own social science, become by definition nonideological and therefore scientifically "objective."

Historically it is understandable why Shils and many of his colleagues came to view "ideological politics" as they do. The concept developed out of the naturalistic, pragmatic tradition of American social science. In 1910 the founders of American social science believed that "metaphysics" was the sworn enemy of objective "science" and therefore the root of social evil. The crises of the thirties forced them to transfer their concept of "metaphysics" into the language of politics. The result was "ideology," the metaphysics of politics, the new enemy of science and the new root of social evil. Ideology, like metaphysics, was absolutist, transcendental, divisive, and empirically inaccurate; science, conversely, was relativistic, objective, consensual, and empirically accurate. Such a schema was, however, clearly not itself "objective." It was, rather, philosophical and profoundly value-laden. (25) As an explanatory hypothesis, it was so simplistic as to become mere caricature. To explain Stalinism, Nazism, and the activities of American intellectuals in the thirties as stemming primarily from such an "ideological quality" reduced history to a morality play. (26) The conviction that "ideology," so defined, represented the major challenge to both society and the life of the mind was itself a belief that could only grow powerful in a certain kind of historical period. The preoccupations that Shils and many members of his generation share ties them to the image of the "ideologists" they attack: both groups believe that "ideologies" can in fact, consciously and directly, change the world. While that possibility has stirred hope in some, it repels Shils and his colleagues To a large extent, however, both groups start from the same intellectual assumptions.

In spite of its analytically dubious and historically partisan meaning, however, Shils' concept of "ideology" is useful to him because of its moral function. First, it denigrates any fundamental criticism of the status quo as both irrational and dangerous. Second, it establishes from another direction the conclusion that the existent social structure marks out the limits of rational analysis. Third, as with his use of the concept "intellectual," it shifts the basis of moral judgment from questions of substantive criticism to the function of social preservation.

Perhaps of greatest importance, the concept of "ideology" establishes the 
nature and value of its alleged intellectual and moral opposite. The various sciences, including the social sciences, "have not been ideological," Shils insists. "Indeed, they have had a solvent effect on ideologies and in a sense are anti-ideological." (27) Since the characteristics of "science" are obviously contrary to those of "ideology," it follows that "science" must be open, empirical, objective, and universally verifiable. Since the characteristic attitudes of science can be applied to the study of societies, it also follows that there is an objective social science. Since Shils claims those characteristics as his own, it follows, finally, that his perspective represents an "objective" analysis of politics. Science, which is always proving things in modern society, thus comes ultimately to prove that the status quo indeed represents the true and the good.

Shils sperifically rejects the increasingly accepted contention that science itself is "ideological," and his argument is most revealing. In spite of the many statements that he adduces as "reasons" supporting his rejection, his argument revolves essentially around definitions. As he acknowledges at one point, science is not ideological "in the sense in which ideology has been defined and used in the foregoing analysis." (28) Indeed, given his definition, he is correct. Recognizing the narrowness and moral implications of his definition, as well as the tautologous nature of his argument, it is clear that he proves nothing about the social functions and value assumptions that in fact characterize the very complicated phenomena we casually refer to as "science."

One of the most significant intellectual developments of the last fifteen years has been the maturation of a sophisticated and provocative critique of the idea of "objective science". Whatever one thinks of the work of such individuals as Michael Polanyi, Thomas Kuhn, Noam Chomsky, Herbert Marcuse, Norman O. Brown, Alvin Gouldner, Robert Friedrichs, R. D. Laing, and many others, it is surely indefensible to dismiss their varied arguments by merely defining out of existence the problems they raise. Professor Shils has the learning and intellect to meet such approaches, and analyze them fairly and fully. That would be a major contribution to contemporary social thought, one that would shed light on the role of intellectuals, the function of science, and the nature of human reason. Hopefully he will accept the challenge in his forthcoming works and help advance our general understanding of real problems. His moral schema serves only to deflect his own considerable intellectual powers and to distort our understanding of both past and present.

The careers of Slichter, Leith, and Russell illustrate the rise of the practical, institutionalized "service intellectual". Critics might dismiss them as mere technicians or even as "servants of power". Such a "new left" evaluation, however, surely lacks subtlety as much as does the more traditional view which would picture them as heralding a new age of objectivity, benevolence, and progress. We are indebted to scholars such as Shils for pointing out many of the complexities involved in studying the role and significance of such individuals. Yet hopefully we are beyond the polemics that inform his analysis. Evaluating the career and role of the "service intellectual" involves at some point inescapable moral judgments. By making such judgments openly 
and by setting out the criteria fully, scholars can deal more adequately with the problem of the "proper role" of the intellectual and at the same time perhaps place their historical analyses on whatever reasonably "objective" basis it is possible for human reason to attain.

Edward A. Purcell, Jr. University of Missouri-Columbia

\section{Notes}

1. For treatments of the term "intellectual" as well as of the activities of such individuals see: Richard Hofstadter, Anti-Intellectualism in American Life (New York, 1962); Laurence R. Veysey, The Emergence of the American University (Chicago, 1965); Raymond Williams, Culture and Society, 1780-1950 (New York, 1958); Christopher Lasch, The New Radicalism in America, 1889-1963: The Intellectual as a Social Type (New York, 1965); Lewis A. Coser, Men of Ideas: A Sociologist's View (New York, 1965); Philip Rieff, ed., On Intellectuals: Theoretical Studies/Case Studies (Garden City, N. Y., 1970).

2. Charles Sumner Slichter apparently claimed that he wanted to have $\$ 50,000$ by the time he was fifty years old. By 1914, when he was fifty, he had succeeded. Charles Kenneth Leith left an estate of almost $\$ 1,700,000$ at his death. By 1928 , Harry L. Russell's yearly income was over $\$ 50,000$.

3. Mark H. Ingraham, Charles Sumner Slichter: The Golden Vector (Madison, Wisconsin, 1972, pp. 3-4.

4. Ibid., 176.

5. Sylvia Wallace McGrath, Charles Kenneth Leith: Scientific Advisor (Madison, Wisconsin, 1971), p. 224.

6. Ibid., p. 65.

7. Ibid., p. 229.

8. Ibid., p. 165 .

9. Ibid., p. 172.

10. Ibid., p. 106.

11. Ibid., p. xi.

12. Edward H. Beardsley, Harry L. Russell and Agricultural Science in Wisconsin (Madison, Wisconsin, 1969), p. 119.

13. Ibid., p. 115.

14. See, for example, Thomas S. Kuhn, The Structure of Scientific Revolutions, 2nd ed. (Chicago, 1970); Robert W. Friedrichs, A Sociology of Sociology (New York, 1970); Theodore Roszak, The Making of a Counter Culture: Reflections on the Technocratic Society and Its Youthful Opposition (Garden City, N. Y., 1969); Noam Chomsky, Problems of Knowledge and Freedom (New York, 1971); Noam Chomsky, Language and Mind, enlarged ed. (New York, 1972): Alvin W. Gouldner, The Coming Crisis of Western Sociology (New York, 1970); Michael Polanyi Personal Knowledge: Toward a Post-Critical Philosophy (Chicago, 1958); C. Wright Mills, The Sociological Imagination (New York, 1959); Robert S. Lynd, Knowledge for What? The Place of Social Science in American Culture (Princeton, New Jersey, 1939); Liam Hudson, The Cult of the Fact: A Psychologist's Autobiographical Critique of His Discipline (New York, 1972); 
Herbert Marcuse, One-Dimensional Man: Studies in the Ideology of Advanced Industrial Society (Boston, 1964); and Paul C. Obler and Herman A. Estrin, eds., The New Scientist: Essays on the Methods and Values of Modern Science (Garden City, N. Y., 1962).

15. Edward Shils, The Intellectuals and the Powers and Other Essays (Chicago, 1972), pp. vii, $x$.

16. Ibid., p. 116.

17. Ibid., p. 195, xii.

18. Ibid., p. 47

19. Ibid., p. 176.

20. Ibid., p. 154.

21. Ibid., p. 192.

22. Leopold Labedz, "The Structure of the Soviet Intelligentsia." Daedalus, 89 (Summer, 1960), 504; Martin Malia, "What is the Intelligentsia?" Ibid., 443.

23. Shils, 27.

24. Ibid., 29.

25. Edward A. Purcell, Jr., The Crisis of Democratic Theory: Scientific Naturalism and the Problem of Value (Lexington, Kentucky, 1973).

26. Ideology, in Shils sense, is perhaps most relevant in dealing with communism and Stalinism. Even here, however, it tends to simplify complex historical phenomena. See, for example, such diverse perspectives as Isaac Deutschler, Stalin: A Political Biography (London, 1949); Milovan Djilas, The Unperfect Society: Beyond the New Class (New York, 1969); and Theodore H. Von Laue, Why Lenin? Why Stalin? (Philadelphia, 1971; Lloyd Gardner, Arthur Schlessinger, Jr., and Hans Morgenthau, The Origins of the Cold War (Waltham, Mass., 1970), pp. 79-102. Recent work on Nazism emphasizes the significance of complex social and economic roots: see especially, Klaus Hiddebrand, "Hitlers ort in Der Geschichte Des Preussisch-Deutschen Nationalstaates," Historische Zeitschrift (December, 1973), 584.632; and "The Coming of the Nazis," Times Literary Supplement, (February 1, 1974), 93-96. Contrary to Shils implications, most American intellectuals kept a considerable distance between themselves and the Communist Party: Charles C. Alexander, Nationalism in American Thought, 1930-1945 (Chicago, 1969); Daniel Aaron, Writers on the Left: Episodes in American Literary Communism (New York, 1961); and Frank Warren, Liberals and Communism (Bloomington, Indiana, 1966). Richard H. Pells' thoughtful and comprehensive Radical Visions and American Dreams: Culture and Social Thought in the Depression Years (New York, 1973) clearly shows the inadequacy of "ideological attitudes" as an explanation for the beliefs and behavior of intellectuals in the thirties. For both a broad treatment of the structural causes of political change, and an appraisal of the harshness of "liberal" societies, see Barrington Moore, Jr., Social Origins of Dictatorship and Democracy: Lord and Peasant in thte Making of the Modern World (Boston, 1966).

27. Shils, The Intellectuals and the Powers and Other Essays, p. 39.

28. Ibid., p. 38. 